\title{
Haemodialysis catheter-related giant right atrial and superior cava thrombi
}

\author{
Laurence Weinberg, ${ }^{1}$ Faizan Zia, ${ }^{1}$ Stan Tay, ${ }^{2}$ Nicholas Roubos ${ }^{3}$
}

'Department of Anaesthesia, Austin Hospital, Heidelberg, Victoria, Australia

${ }^{2}$ Department of Anaesthesia, Royal Darwin Hospital, Tiwi, Northern Territory, Australia ${ }^{3}$ Department of Cardiac Surgery, Austin Hospital, Heidelberg, Victoria, Australia

\section{Correspondence to}

Associate Professor Laurence Weinberg, laurence.weinberg@ austin.org.au

Accepted 2 February 2015
CrossMark

$$
\begin{aligned}
& \hline \text { To cite: Weinberg L, Zia F, } \\
& \text { Tay S, et al. BMJ Case Rep } \\
& \text { Published online: [please } \\
& \text { include Day Month Year] } \\
& \text { doi:10.1136/bcr-2015- } \\
& \text { 209350 }
\end{aligned}
$$

\section{DESCRIPTION}

A 22-year-old woman with end-stage renal failure secondary to membranoproliferative glomerulonephritis presented with methicillin-sensitive Staphylococcus aureus sepsis from an infected haemodialysis catheter-related giant right atrial (RA) thrombus (figure 1A) with an additional mobile thrombus in the superior vena cava (SVC; figure $1 \mathrm{~B}, \mathrm{C})$. The patient was undergoing haemodialysis via a tunnelled dual lumen $13.5 \mathrm{Fr}, 36 \mathrm{~cm}$ Hickman chronic dialysis catheter inserted 9 months prior (figure 1D). Thrombophilia screening was negative.

In view of the size and separate intracardiac locations of the thrombi, management with systemic anticoagulation was considered prohibitive due to risks of fatal pulmonary embolus, right heart failure, infective endocarditis and progressive
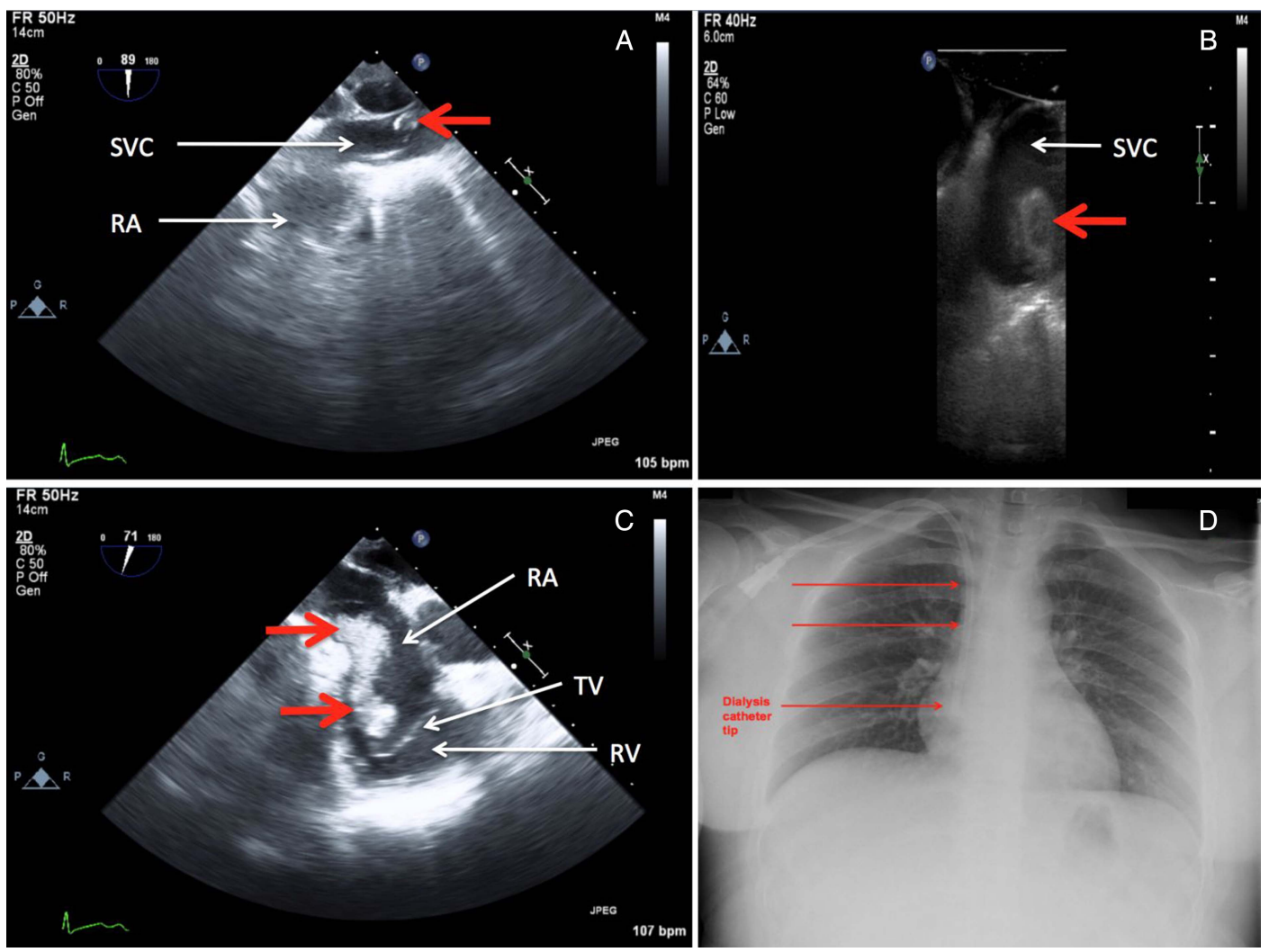

Figure 1 Transoesophageal echocardiography demonstrating cardiac thrombi (thick red arrows) in the SVC-right atrial junction ( $A$ and $B$ ) and a giant thrombus attached to the lateral wall of the RA (C); the thombus extended onto the TV with preservation of the valve leaflets, but not in the RV. A chest radiograph (D) showing a tunnelled dual lumen chronic dialysis catheter (thin red arrows) with the tip positioned in the RA (RA, right atrium; RV, right ventricle; SVC, superior vena cava; TV, tricuspid valve). 


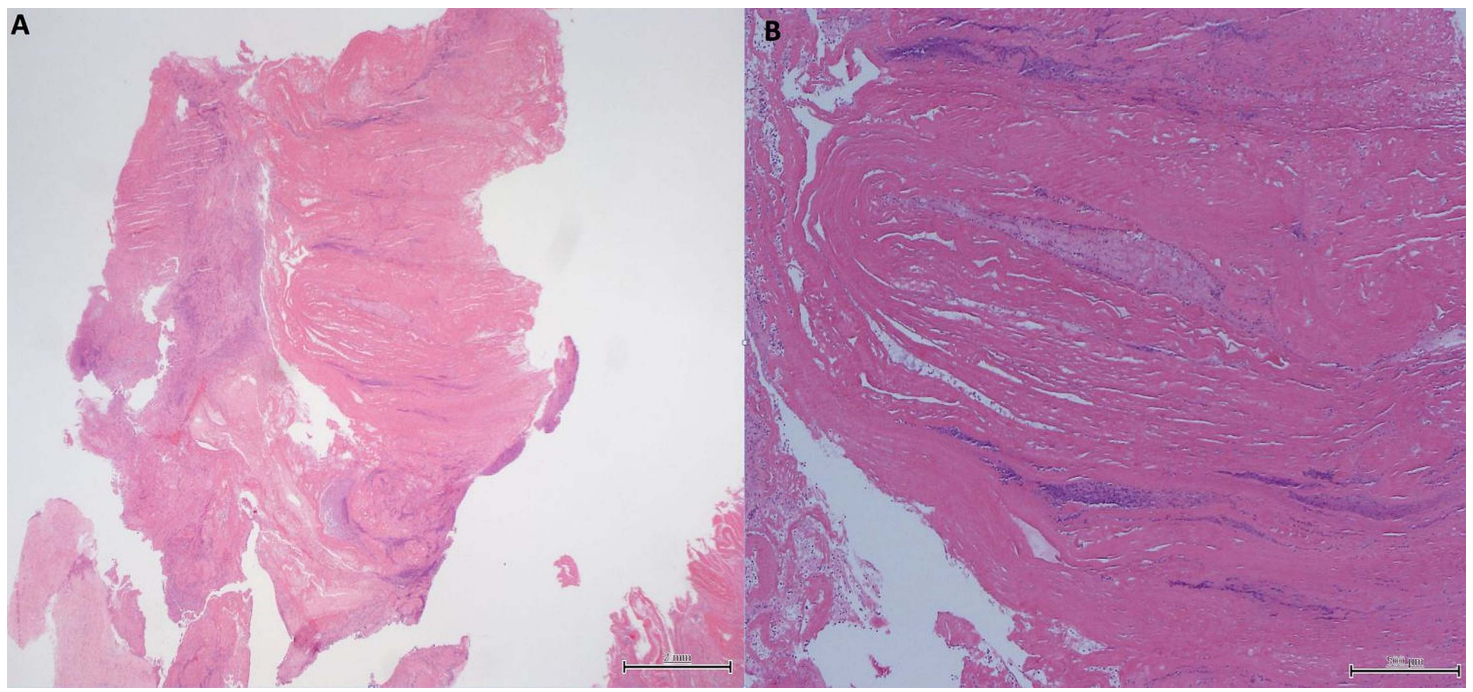

Figure 2 Histological examination showing cardiac thrombus (stained with H\&E) at $\times 40(A)$ and $\times 100$ (B) magnification. There are focally laminated collections of degenerated erythrocytes and fibrin admixed with neutrophils and cellular debris. In the periphery ingrowth of spindle cells representing myofibroblasts are present.

The patient was given intravenous flucloxacillin for 6 weeks, and was discharged 15 days postoperatively after successful conversion to nocturnal automated peritoneal dialysis. The patient is currently being evaluated for renal transplantation.

\section{Learning points}

- There are no established guidelines for management of complex intracardiac catheter-related right atrial (RA) thrombi.

- Early surgical evacuation should be considered in young patients with giant RA thrombi, especially if mobile elements are present, to prevent catastrophic complications such as a massive pulmonary embolus, right heart failure, infective endocarditis and sepsis.

- Frequent echocardiographic screening for intracardiac thrombus formation should be mandatory for all long-standing chronic dialysis catheters whose tips are positioned in the RA.
Contributors LW was responsible for the planning, conduct and writing of the report and obtained all transoesophageal images intraoperatively. FZ was responsible for the literature review, collation of clinical images and writing of the manuscript. ST was involved in preparation of all the images and writing of the report. NR was the principal cardiac surgeon who performed the thrombectomies and was involved in writing of the report. All authors have read and approved the final manuscript. LW was responsible for the overall content and is the guarantor.

\section{Competing interests None.}

Patient consent Obtained.

Provenance and peer review Not commissioned; externally peer reviewed.

\section{REFERENCES}

1 Stavroulopoulos A, Aresti V, Zounis C. Right atrial thrombi complicating haemodialysis catheters. A meta-analysis of reported cases and a proposal of a management algorithm. Nephrol Dial Transplant 2012;27:2936-44.

2 Baskin JL, Pui $\mathrm{CH}$, Reiss U, et al. Management of occlusion and thrombosis associated with long term indwelling central venous catheters. Lancet 2009:37:159-69.

3 NKF/DOQI. Clinical Practice Guidelines for Vascular Access, 2006 Updates. CPG 2.4. http://www.kidney.org/professionals/KDOQI/guideline_upHD_PD_VA/va_guide2.htm (accessed Nov 2014).

Copyright 2015 BMJ Publishing Group. All rights reserved. For permission to reuse any of this content visit

http://group.bmj.com/group/rights-licensing/permissions.

BMJ Case Report Fellows may re-use this article for personal use and teaching without any further permission.

Become a Fellow of BMJ Case Reports today and you can:

- Submit as many cases as you like

- Enjoy fast sympathetic peer review and rapid publication of accepted articles

- Access all the published articles

- Re-use any of the published material for personal use and teaching without further permission

For information on Institutional Fellowships contact consortiasales@bmjgroup.com

Visit casereports.bmj.com for more articles like this and to become a Fellow 